\title{
STUDY HASIL PENETAPAN KADAR ASAM URAT TERHADAP INDIVIDU YANG MENGKONSUMSI JUS KENTANG
}

\author{
Artati $^{1}$, Nurlia Naim² \\ 1 Jurusan Analis Kesehatan Poltekkes Kemenkes Makassar \\ *) tatigiland@rocketmail.com

\section{ABSTRAK}

\begin{abstract}
Study Hasil Penetapan Kadar Asam Urat Terhadap Individu Yang Mengkonsumsi Jus Kentang. (pembimbing: Hj.Nurlia Naim dan Leonardus). Penyakit asam urat ini banyak terjadi di masyarakat dan dapat di kategorikan sebagai salah satu penyakit yang paling umum terjadi, asam urat disebabkan dari makanan dan minuman yang mempunyai kadar protein yang tinggi. Dengan mengkonsumsi kentang yang mempunyai kandungan gizi protein yang rendah maka kentang dapat di jadikan sebagai makanan yang dapat menetralisirkan asam urat dan beberapa kandungan gizi yang dapat menurunkan kadar purin. Ahli Gizi Holistik, Luke Continho dalam Helmi Ade Saputra menjelaskan manfaat kesehatan dari jus kentang mentah seperti yang dilansir dari laman Thehealthsite jika menderita asam urat yang menyebabkan akumulasi kristal dijari kaki dan sendi. Jenis penelitian ini adalah eksperimen semu laboratorik (Quasy experiment) yaitu mengetahui perbandingan study hasil penetapan kadar asam urat terhadap individu yang mengkonsumsi jus kentang. Penelitian ini dilaksanakan pada tanggal 6 juli 2018 di laboratorium kimia klinik analis kesehatan poltekkes makassar. Dari penelitian yang telah dilakukan terhadap 14 sampel penderita asam urat yang mengkonsumsi jus kentang di dapatkan $85,7 \%$ terjadi penurunan. Mengingat bahwa penyakit asam urat bukanlah penyakit yang biasa maka peneliti menyarankan bagi penderita asam urat dapat mengkonsumsi jus kentang.
\end{abstract}

Kata kunci : Jus Kentang, Asam Urat

\section{Study Of Determination Of Uric Acid Levels On Individuals That Consume Potato Juice Artati1, Nurlia Naim1}

1 Department of Health Polytechnic Department of Health Makassar

*) tatigiland@rocketmail.com

\section{ABSTRACT}

Study of the Results of Determining Uric Acid Levels for Individuals Consuming Potato Juice. (advisor: Hj. Nurlia Naim and Leonardus). Gout is a lot happening in the community and can be categorized as one of the most common diseases, gout is caused by foods and beverages that have high protein content. By consuming potatoes that have low protein content, the potatoes can be made as food that can neutralize uric acid and some nutrients that can reduce purine levels. Holistic Nutritionist, Luke Continho in Helmi Ade Saputra explains the health benefits of raw potato juice as reported by the Thehealthsite page if you suffer from gout which causes accumulation of crystals in the feet and joints. This type of research is a laboratory quasi-experiment (Quasy experiment), which is to compare the study results of uric acid levels for individuals who consume potato juice. This research was conducted on July 6, 2018 in the Makassar chemical clinic health analyst clinic Makassar. From the research that has been conducted on 14 samples of gout sufferers who consumed potato juice in getting $85.7 \%$ there was a decrease. Given that gout is not a common disease, researchers suggest that gout sufferers can consume potato juice.

Keywords: Potato Juice, Gout

\section{PENDAHULUAN}

Kentang mulai dikenal di Eropa pada abad ke 16 yang biasa dipakai dalam menu diet sebagai pengganti nasi. Hampir semua orang, baik di pedesaan maupun di perkotaan tahu dan mengenal. kentang digemari oleh hampir semua individu karena rasanya yang begitu khas. Bahkan di negara Prancis, Belanda dan beberapa negara lain, kentang dijadikan sebagai makanan pokok. Kentang merupakan tanaman yang berasal dari Amerika Selatan yang tumbuh di iklim yang sejuk.
Jika di budidayakan di daerah yang beriklim tropis maka dapat di tanam di dataran tinggi, tanaman ini tumbuh tidak terlalu tinggi dan batangnya tidak berkayu, kentang yang biasanya di makan berasal dari batangnya di bawah permukaan tanah yang berisi cadangan makanan hingga menjadi besar dan berisi. selain itu, kentang juga mempunyai bentuk yang sederhana dapat diolah menjadi berbagai sayuran maupun di buat sebagai jus dan b 2 seperti vitamin B6, B5, vitamin $E$ dan vitamin C (Mulyanto devinda 2012). Banyak manfaat yang dapat diperoleh dengan 
mengkonsumsi kentang salah satunya adalah kentang berkhasiat untuk meningkatkan $\mathrm{pH}$ dalam tubuh, karena kentang terdapat kandungan mineral, potasium dengan kadar alkalin yang tinggi sehingga kentang dapat menetralkan asam urat dalam darah dalam hal ini kandungan kentang berupa vitamin B6, B5, vitamin C dan vitamin $E$ inipun juga berpengaruh untuk menetralkan asam urat. Asam urat adalah senyawa nitrogen yang dihasilkan dari metabolisme di dalam tubuh, baik itu metabolisme purin maupun metabolisme DNA (deoksiribonukleotida).

Purin adalah salah satu senyawa basa organik yang menyusun asam nukleat (asam inti dari sel) dan termasuk dalam kelompok asam amino, unsur pembentuk protein. Jadi asam urat terbentuk akibat metabolisme purin di dalam tubuh dan purin berlebihan berasal dari makanan yang mengandung protein. Penyakit asam urat ini banyak terjadi di masyarakat dan dapat di kategorikan sebagai salah satu penyakit yang paling umum terjadi, asam urat disebabkan dari makanan dan minuman yang dapat merangsang pembentukan asam urat, jenis makanan ini adalah makanan yang mempunyai kadar protein yang tinggi. 3 dengan mengkomsumsi kentang yang mempunyai kandungan gizi protein yang rendah maka kentang dapat di jadikan sebagai makanan yang dapat menetralisirkan asam urat dan beberapa kandungan gizi yang dapat menurunkan kadar purin.

Permasalahannya adalah sampai saat ini mengkomsumsi kentang belum di ketahui dengan jelas dan pasti dapat menurunkan kadar asam urat terhadap individu. Mengacu pada uraian latar belakang tersebut di atas penulis tertarik untuk melakukan penelitian guna membuktikan kemampuan kentang untuk menetralisirkan asam urat dengan cara pemberian jus kentang.

\section{METODE PENELITIAN}

Fase Pra analitik. Diawali dengan Pembuatan jus kentang dengan Menyiapkan alat dan bahan, Mencuci kentang beserta kulitnya dikupas. 3) Kemudian 2 buah kentang berukuran sedang, di buat beberapa potongan kecil. Selanjutnya kentang yang sudah dipotong di masukan kedalam blender. Kentang yang telah hancur di saring dan kemudian ditampung dalam wadah (gelas), Jus kentang yang telah di buat di komsumsi 2 kali sehari (pagi dan malam hari).

Pengambilan darah kapiler meliputi: Pengambilan darah kapiler untuk kontrol dan sampel penelitian. Kontrol $=$ sebelum mengkonsumsi jus kentang. Sampel = sesudah mengkonsumsi jus kentang, menusuk jari manis/tengah pasien menggunakan lancet. menghapus tetesan darah yang pertama keluar menggunakan kapas kering.

Fase Analitik meliputi, Pemeriksaan asam urat

, Memasang strip asam urat pada alat autocheck. Lalu strip asam urat yang telah terpasang didekatkan pada jari pasien yang sudah di tusuk. Alat akan membaca setelah 15 detik. Kemudian dibaca hasilnya.

\section{HASIL}

Berdasarkan hasil penelitian yang telah dilakukan di laboratorium jurusan analis kesehatan poltekkes makassar terhadap 14 specimen pada penderita asam urat yang mengkonsumsi jus kentang. (Tabel 4.1).

Dari tabel tersebut (Tabel 4.2) menunjukan bahwa penetapan kadar asam urat terhadap individu yang mengkonsumsi jus kentang di dapatkan nilai rata-rata 6,736 dan standar deviasi 1,1699 untuk yang sebelum mengkonsumsi jus kentang sedangkan sesudah mengkonsumsi jus kentang di dapatkan nilai rata-rata 5,421 dan standar deviasi 1,0349.

\section{PEMBAHASAN}

Minum segelas jus kentang mentah dapat menjadi kebiasaan sehat yang bermanfaat diterapkan sehari-hari. Ahli Gizi Holistik, Luke Continho dalam Helmi Ade Saputra menjelaskan manfaat kesehatan dari jus kentang mentah seperti yang dilansir dari laman Thehealthsite jika menderita asam urat yang menyebabkan akumulasi kristal dijari kaki dan sendi, maka dapat mencoba meminum segelas jus kentang mentah dua kali sehari, setiap pagi dan malam dapat menurunkan asam urat. Kadar asam urat yang tinggi bisa mejadi tanda bahwa ginjal tidak bekerja dengan baik. Jus kentang mentah bisa mengeluarkan asam urat keluar dari tubuh dan meningkatkan fungsi ginjal. Kadar asam urat biasanya selalu naik dan turun jika mengkonsumsi makanan yang berbeda atau makan mengandung kadar purin yang 
tinggi. Dengan adanya kehadiran dari kentang yang mana juga mengandung sumber vitamin B6, potassium, kalsium, vitamin $\mathrm{C}$ dan mangan. Kentang juga memiliki penuh anti-oksidan, senyawa flavonoid dan fitonutrien yang dapat menangkal radikal bebas.

manfaat kesehatan yang didapatkan dengan mengkonsumsi jus kentang, yaitu Asam urat dengan memiliki sifat antiinflamasi, jus kentang sendiri juga mengurangi terjadinya pembengkakan pada persendian yang kemudian disebabkan oleh kelebihan asam urat 56 yang terjadi pada tubuh. sehingga meminum jus kentang dapat menurunkan asam urat. Sumber makanan yang mengandung purin, antara lain seperti seafood, daging, jerohan, kacangkacangan biji kering. Pada asupan vitamin C ditemukan pada kentang adanya hubungan bermakna antara asupan vitamin $\mathrm{C}$ terhadap kadar asam urat pada remaja laki-laki. Vitamin C merupakan mikronutrien yang berperan dalam berbagai reaksi enzimatik dan non enzimatik. Peningkatan konsentrasi vitamin $\mathrm{C}$ dapat menghambat reabsopsi asam urat. Vitamin C memodulasi konsentrasi serum asam urat melalui efek uricosuriknya. Vitamin $\mathrm{C}$ dan asam urat diserap melalui pertukaran anion di tubulus proksimal ginjal. Penelitian sebelumnya yang dilakukan pada manusia dan hewan telah menunjukan bahwa pemberian vitamin $\mathrm{C}$ meningkatkan aliran plasma ginjal dan laju filtrasi glomerulus dan melemahkan peningkatan tekanan arteri. Vitamin $C$ dapat mengurangi stres oksidatif dan peradangan karena itu menurunkan sintesis asam urat. Asupan vitamin C pada subjek penelitian sebagian besar tinggi sebesar lebih dari $60 \mathrm{mg}$ per hari. Asupan vitamin C normalnya $\pm 60 \mathrm{mg}$ per hari. Dalam penelitian ini terdapat hubungan bermakna positif, hal ini terjadi karena konsumsi asupan vitamin $C$ subjek kurang dari $500 \mathrm{mg}$ per hari dan sebagian besar 57 subjek kadar asam urat dalam kategori normal.

Meningkatnya ekskresi kadar asam urat tergantung pada jumlah vitamin $C$ yang di konsumsi. Kelebihan vitamin $C$ yang berasal dari makanan tidak menimbulkan gejala, tetapi konsumsi vitamin $\mathrm{C}$ berupa suplemen secara berlebihan setiap harinya dapat menganggu ginjal. Sedangkan pada penelitian sebelumnya menyebutkan konsumsi vitamin $\mathrm{C}$ lebih dari $500 \mathrm{mg}$ per hari dalam bentuk suplemen selama 2 bulan dapat menurunkan kadar asam urat. Penelitian ini di lakukan dengan cara mengkonsumsi jus kentang selama 1 hari yaitu pagi dan malam hari, bahwa ternyata dalam 1 hari ini sudah dapat menurunkan asam urat walaupun hanya sedikit namun cara ini dapat di lakukan khususnya bagi penderita asam urat. Namun tetap saja harus mengontrol makanmakanan yang mengandung kadar protein yang tinggi walaupun mengkonsumsi jus kentang namun tetap mengkonsumsi makanan yang di larang maka sama saja tidak terjadi perubahan sama sekali. Jus kentang ini dapat di konsumsi selama 1-2 minggu jika ingin mendapatkan hasil penurunan yang lebih baik. Kekurangan dari penelitian ini adalah jumlah sampel yang tidak mencukupi yaitu dari 16 sampel yang direncanakan hanya 14 sampel yang didapatkan.

\section{KESIMPULAN}

Berdasarkan dari hasil pemeriksaan asam urat terhadap individu yang mengkonsumsi jus kentang pada masyarakat di kota pangkep dan di kota Makassar yang di lakukan di Laboraturium kimia klinik politeknik kesehatan jurusan analis kesehatan pada tanggal 6 juli s/d 22 juli 2018, menggunakan sampel penderita asam urat sebanyak 14 orang maka di dapat disimpulkan bahwa Ho di tolak dan Ha diterima sehingga terdapat perbedaan yang signifikan antar kadar asam urat sebelum dan sesudah mengkonsumsi jus kentang.

\section{SARAN}

Berdasarkan penelitian yang telah dilaksanakan maka peneliti menyarankan : 1. Mengingat bahwa penyakit asam urat bukanlah penyakit yang biasa maka peneliti menyarankan bagi penderita asam urat dapat mengkonsumsi jus kentang.

2. Diharapkan di masa yang akan datang dapat digunakan sebagai salah satu sumber data untuk penelitian lebih lanjut, variabel yang berbeda, jumlah sampel yang lebih banyak, tempat yang berbeda dan tetap berhubungan dengan kadar asam urat.

\section{DAFTAR PUSTAKA}

Adib M, 2011. Pengetahuan Praktis Ragam Penyakit Mematikan Yang Paling Sering Menyerang Kita. Yogyakarta: Buku Biru 
Anonim, 2011. Bab II Tinjauan Pustaka Pemeriksaan Asam Urat. Diakses Pada Tanggal 4 Juli 2018. Repository.unimus.ac.id.

Apriyanti M, 2012. Meracik Sendiri Obat Dan Menu Sehat Bagi Penderita Asam Urat. Yogyakarta: Pustaka Baru Press. Buku Panduan Multi-Monitoring System AUTOCHECK, 2014. Jakarta: PT.Mega Pratama Medicalindo.

Dalimartha S, 2011. Resep Tumbuhan Obat Untuk Asam Urat. jakarta: penebar swadaya. Hidayah A, 2011. Kesalahan-kesalahan Pola Makan Pemicu Seabrek Penyakit Mematikan. Yogyakarta: Buku Biru

Helmi Ade Saputra.https://lifestyle okezone.com > lifestyle > health.

Jessica S,M,Sugiarto C,Fenny. Perbandingan Kadar asam urat darah dengan metode spektrofotometer dan metode Electrodebased biosensor. Diakses pada tanggal 4 juli 2018. Digilib.unimus.ac.id Junaidi I, 2013. Rematik Dan Asam Urat. Jakarta: PT Bhuana IImu Populer.

Mulyanto D, 2012. Panjang Umur Dengan Kontrol Kolesterol Dan Asam Urat. Yogyakarta: Cahaya Atma Pustaka. Pursriningsih S.S,
2015. Hubungan Asupan Purin, Vitamin C Dan Aktivitas Fisik Terhadap Kadar Asam Urat Pada Remaja Laki-Laki. Diakses Pada $5 \quad$ April 2018. http://ejournals1.undip.ac.id/indeks.php/jn c

\section{Yogyakarta: Garailmu}

Pramukti Dian Setianingrum, dkk. Artikel.

pemberian air rebusan daun salam (syzygium polyanthum) terhadap penurunan kadar asam urat pada penderita asam urat di dusun kadisoro desa gilangharjo kecamatan pandak kabupaten bantul diy tahun 2017

Rahmawati S, 2010. Menu Sehat Asam Urat. Yogyakarta: PT Pustaka Insan Madani. Rushdie, 2009. Cara Murah Hidup Sehat Tanpa Zat-Zat Kimia.

Zulkarnain H, 2013. Budidaya Sayuran Tropis. Jakarta: PT Bumi Aksara. 


\section{LAMPIRAN}

TABEL 4.1 Hasil Pemeriksaan Kadar Asam Urat Terhadap Individu Yang Mengkonsumsi Jus Kentang

\begin{tabular}{|c|c|c|c|c|c|c|}
\hline \multirow[b]{2}{*}{ NO } & \multirow[b]{2}{*}{$\begin{array}{c}\text { Kode } \\
\text { Sampel }\end{array}$} & \multirow[b]{2}{*}{$\begin{array}{l}\text { Umur } \\
\text { (th) }\end{array}$} & \multirow{2}{*}{$\begin{array}{c}\text { Jenis K } \\
\text { elamin Laki- } \\
\quad \text { laki/ } \\
\text { Perempuan } \\
\end{array}$} & \multicolumn{2}{|c|}{ Hasil Pemeriksaan } & \multirow[b]{2}{*}{ Ket } \\
\hline & & & & $\begin{array}{c}\text { Sebelum } \\
\text { meminum jus } \\
\text { kentang }\end{array}$ & $\begin{array}{c}\text { Sesudah minum } \\
\text { jus kentang }\end{array}$ & \\
\hline 1 & A & 60 & $P$ & $8,0 \mathrm{mg} / \mathrm{dl}$ & $4,6 \mathrm{mg} / \mathrm{dl}$ & $\downarrow$ \\
\hline 2 & B & 60 & $P$ & $7,1 \mathrm{mg} / \mathrm{dl}$ & $6,2 \mathrm{mg} / \mathrm{dl}$ & $\downarrow$ \\
\hline 3 & C & 56 & $P$ & $7,8 \mathrm{mg} / \mathrm{dl}$ & $5,4 \mathrm{mg} / \mathrm{dl}$ & $\downarrow$ \\
\hline 4 & D & 50 & L & $8,5 \mathrm{mg} / \mathrm{dl}$ & $6,2 \mathrm{mg} / \mathrm{dl}$ & $\downarrow$ \\
\hline 5 & $E$ & 45 & $P$ & $8,2 \mathrm{mg} / \mathrm{dl}$ & $5,1 \mathrm{mg} / \mathrm{dl}$ & $\downarrow$ \\
\hline 6 & $\mathrm{~F}$ & 63 & $P$ & $7,5 \mathrm{mg} / \mathrm{dl}$ & $6,2 \mathrm{mg} / \mathrm{dl}$ & $\downarrow$ \\
\hline 7 & G & 63 & $\mathrm{P}$ & $7,1 \mathrm{mg} / \mathrm{dl}$ & $\begin{array}{c}6,7 \\
\mathrm{mg} / \mathrm{dl}\end{array}$ & $\downarrow$ \\
\hline 8 & $\mathrm{H}$ & 68 & $L$ & $6,7 \mathrm{mg} / \mathrm{dl}$ & $6,3 \mathrm{mg} / \mathrm{dl}$ & $\downarrow$ \\
\hline 9 & I & 30 & $P$ & $6,2 \mathrm{mg} / \mathrm{dl}$ & $3,8 \mathrm{mg} / \mathrm{dl}$ & $\downarrow$ \\
\hline 10 & $J$ & 65 & $P$ & $5,2 \mathrm{mg} / \mathrm{dl}$ & $3,7 \mathrm{mg} / \mathrm{dl}$ & $\downarrow$ \\
\hline 11 & $\mathrm{~K}$ & 50 & $P$ & $5,6 \mathrm{mg} / \mathrm{dl}$ & $5,4 \mathrm{mg} / \mathrm{dl}$ & $\downarrow$ \\
\hline 12 & $L$ & 50 & $P$ & $5,8 \mathrm{mg} / \mathrm{dl}$ & $5,8 \mathrm{mg} / \mathrm{dl}$ & $\rightarrow$ \\
\hline 13 & $M$ & 45 & $P$ & $5,2 \mathrm{mg} / \mathrm{dl}$ & $6,5 \mathrm{mg} / \mathrm{dl}$ & 4 \\
\hline 14 & $\mathrm{~N}$ & 40 & $\mathrm{P}$ & $5,4 \mathrm{mg} / \mathrm{dl}$ & $4,0 \mathrm{mg} / \mathrm{dl}$ & $\downarrow$ \\
\hline
\end{tabular}

Sumber : Data primer 2018

Keterangan :

$\downarrow$ : terjadi penurunan

4: terjadi peningkatan

tidak terjadi perubahan (sama)

Tabel 4.2 hasil uji statistik penetapan kadar asam urat yang mengkonsumsi jus kentang.

\begin{tabular}{cccccc}
\hline Kelompok & N & Mean & SD & Thitung & T.tabel \\
\hline Sebelum & 14 & 6,736 & 1,1699 & \multirow{2}{*}{3,733} & \multirow{2}{*}{3,012} \\
Sesudah & 14 & 5,421 & 1,0349 &
\end{tabular}

Sumber : Data primer 2018 